\title{
Pengaruh Motivasi dan Pengembangan Karir Serta Softskill Terhadap Kinerja Karyawan
}

\author{
Andy Hakim \\ STAIN Mandailing Natal, Indonesia \\ Email: andyhakim@stain-madina.ac.id \\ Submitted: 01/10/2021; Accepted: 29/10/2021; Published: 30/10/2021
}

\begin{abstract}
Abstrak-Perkembangan teknologi mempermudah perusahaan dalam proses managerial untuk mengetahui strategi dan teknik bertahan, keberlangsungan dan tumbuh berkembangnya hidup perusahaan tergantung kepada ketersediaan sumberdaya yang perusahaan miliki terutama sumberdaya manusia yang merupakan komponen utama yang paling berharga dalam setiap aktivitas dan kegiatan sebuah perusahaan, pentingnya mengetahui kualitas kinerja sumberdaya manusia pada perusahaan atau biasa disebut dengan karyawan untuk membantu managemen perusahaan dalam menapai tujuan perusahaan perlu dilakukan perubahan dan peningkatan Kinerja karyawan terhadap perusahaaan, hal tersebut mengakibatkan perlu diketahui pengaruh dan faktor yang dapat mempengaruhi karyawan dalam meningkatakan Kinerja karyawan, dalam melihat beberapa faktor yang mempengaruhi Kinerja karyawan pada penelitian ini seperti pengaruh motivasi, pengembangan karir serta softskill yang dimiliki karyawan, data hasil reponden yaitu karyawan diolah menggunakan SPSS untuk mempermudah tahapan menemukan pengaruh terhadap masing-masing variabel. Hasil yang ditemukan berupa pengaruh variabel Motivasi dan pengembangan karir memiliki nilai signifikan yang tinggi dan berpengaruh positif sementara nilai softskill memiliki pengaruh negatif.
\end{abstract}

Kata Kunci: Motivasi; Pengembangan Karir; Softskill; Kinerja Karyawan; SPSS

\begin{abstract}
Technology developments make it easier for companies in the managerial process to find out strategies and techniques for survival, the sustainability and growth of the company's life depends on the availability of resources that the company has, especially human resources which are the most valuable main component in every activity and activity of a company, the importance of knowing the quality performance of human resources in the company or commonly referred to as employees to assist company management in achieving company goals needs to be changed and improved employee performance to the company, this results in the need to know the influences and factors that can affect employees in improving employee performance, in looking at several factors that affect the performance of employees in this study such as the influence of motivation, career development and soft skills possessed by employees, data from respondents, namely employees are processed using S PSS to facilitate the stages of finding the effect on each variable. The results found in the form of the influence of the variable motivation and career development have a high significant value and have a positive effect while the value of soft skills has a negative influence.
\end{abstract}

Keywords: Motivation; Career Development; Soft Skills; Employee Performance; SPSS

\section{PENDAHULUAN}

Manusia merupakan sumber daya yang sangat penting dalam sebuah perusahaan, sumber daya manusia dapat digantikan oleh mesin tetapi mesin itu sendiri tidak bisa lepas dari kontrol dan pengawasan manusia, sebuah perusahaan dapat mencapai tujuan dari mulai didirikan sebuah perusahaan hingga tumbuh dan berkembang juga tidak terlepas dari faktor adanya keuletan sumber daya manusia, dalam sebuah perusahaan sumber daya manusia biasa disebut dengan karyawan. Jenis karyawan juga banyak seperti karyawan tetap, karyawan magang, karyawan honor dan lain-lain, karyawan sering disebut dengan asset paling berharga yang dimiliki oleh perusahaan (Aliyyah, 2020).

Pada era yang penuh teknologi dan perang ekonomi dunia saat ini merupakan era yang sangat menantang bagi banyak perusahaan adapun fenomena yang banyak terjadi saat ini seperti sangat banyak menghadapi persaingan dunia bisnis yang sangat ketat baik pesaingan antar perusahan hingga pesaingan dan kewaspadaan terhada faktor eksternal dan internal. Masalah serius yang dihapadi perusahaan bukanlah masalah yang berasal dari faktor eksternal melainkan faktor internal karena faktor internal sendiri yang dapat mewujudkan tercapainya cita-cita sebuah perusahaan, adapun faktor internal salah satunya adalah sumber daya manusia atau karyawan perusahaan (Phadermrod, Crowder, \& Wills, 2019).

Tumbuh dan berkembangnya sebuah perusahaan dapat dilihat dari kinerja karyawan berikan kepada perusahaan karena kinerja karyawan itu sendiri berkaitan erat dan berkaitan langsung terhadap seluruh aktivitas perusahaan dan dapat disebut karyawan sebagai jantung dan otaknya sebuah perusahaan (Robo, Trisno, Sunardi, \& Santosa, 2018). Kinerja karyawan pada umumnya berasal dari kata kinerja yaitu sebuah hasil yang terlihat pada sebuah perusahaan sebagai perwujudan kegiatan yang telah diberikan oleh seseorang dengan kesukarelaan yang penuh dan pencapaian. kinerja juga merupakan hasil dari pekerjaan yang berkaitan dengan tujuan organisasi seperti kualitas dan efisiensi lain dari efektivitas. Terdapat beberapa faktor yang mempengaruhi kinerja antara lain pengembangan karir, motivasi dan softskill.

Pentingnya menjaga kinerja karyawan sama dengan pentingnya menjaga keberlangsungan dan keberhasilan hidup sebuah perusahaan. Banyak keluahan dari karyawan disebabkan kurangnya apresiasi dan dukungan perusahaan terutama dalam hal kesejahteraan karyawan, kurangnya pengertian sebuah perusahaan terhadap mengakibatkan menurunnya kualitas dan kuantitas kerja karyawan terhadap perusahaan, hal ini jika biarkan akan menjadi ancaman internal terhadap sebuah resiko perusahaan dan membuat rendahnya kinerja karyawan (Hidayat, 2015).

Beberapa perusahaan melakukan upaya untuk meningkatkan kinerja karyawan untuk mempercepat pencapaian tujuan yang ingin diraih sebuah perusahaan dengan melakukan usaha seperti memberikan reward(Apriyanti, Bahrun, \& Finthariasari, 2020). Cara lainnya melalui memberikan motivasi sebagai upaya meyakinkan karyawan terhadap 
memberikan yang terbaik kepada perusahaan, meningkatkan softskill agar karyawan dapan membantu perusahaan menghadapi banyak permaslaahan yang akan timbul kedepannya, hingga memberikan pengembangan karir yang nyata kepada karyawan sebagai hasil dari upaya meningkatkan kinerja karyawan(Aren \& Nayman Hamamci, 2020).

Pada penelitian ini dilakukan penelitian terhadap penigkatan kinerja karyawan dilakukan dengan melihat pengaruh-pengaruh yang berpotensi dan signifikan dalam meningkatkan kinerja karyawan, dimana hasil yang diperoleh dari masig-v masing pendapat karyawan terkait diolah menggunakan aplikasi statistic berupa SPSS versi 22, hal ini mempermudah dalam mengetahui hasil yang ingin didapatkan berdasarkan hasil dari responden karyawan(Hoffmann, Spiegl, Hauck, Bühren, \& Gonschorek, 2013).

Penelitian terdahulu memperlihatkan pengaruh motivasi terhadap karyawan memiliki signifikan dan bernilai positif terhadap kinerja karyawan, penelitian yang dilakukan oleh Akbar, penelitian terdahulu lainnya memperlihatkan penggunaan SPSS sangat membantu dalam mengolah data statistik yang sangat banyak(Akbar, Prasetiyani, \& Nariah, 2020). penelitian yang dilakukan oleh Ismail dalam melihat hasil pegembangan karir dalam meningkatkan kinerja karyawan juga memiliki pengaruh baik terhadap peningkatan kualitas kinerja karyawan (Ismail, Hasan, \& Musdalifah, 2018). Pada penelitian ini ingin diketahui terhadap karyawan pengaruh apa saja yang dapat meningkatkan kinerja karyawan terhadap beberapa vaktor atau yang lebih dikenal dengan beberapa variabel seperti pengembangan karir, motivasi dan softskill, dari keseluruhan variabel tersebut akan diketahui focus perusahaa terhadap memperhatikan kebutuha karyawan yang menyebabkan meingkatnya Kinerja karyawan.

\section{KERANGKA TEORI}

Metode penelitian merupakan hal-hal yang dilakukan dalam sebuah penelitian yang bertujuan memperjelas arah dan tahapan dalam sebuah penelitian, adapun tahapan penelitian dilakukan dalam melihat pengaruh beberapa variabel seperti pengaruh motivasi, pengembangan karir dan softskill, tahapan ini dimulai dengan mengumpulkan data dari beberapa narasumber dalam bentuk kuesioner sehingga data tersebut dapat dihitung dan diolah menggunakan aplikasi statistic SPSS Versi 22

\subsection{Pengembangan Karir}

Pengembangan karir merupakan salah satu hal yang paling disukai oleh banyak pekerja atau karyawan karena hal tersebut merupakan tahapan dalam memperlihatkan seberapa kuat proses yang mampu membentuk seseorang dalam membangun identitsas diri seseorang tersebut, dengan adanya pegembangan karir maka seseorang dapat melakukan kegiatan dalam menempah dan meningkatkan kualitas dan kuantitas diri, hal ini juga merupakan pintu gerbang dalam menentukan baik dan tidaknya masa depan karir seseorang (Okagbue, Oguntunde, Obasi, \& Akhmetshin, 2021).

\subsection{Motivasi}

Motivasi merupaka kegiatan menyemangati, menyeru, mengajak seseorang ataupun sekelompok masyarak yang mengajak kepada hal yang diserukan, motivasi juga dapat berupa inspirasi seseorang untuk mencapai target-target dalam hidup, adanya motivasi dapat mengumpulkan semangat dan perubahan pola pikir seseorang menjadi lebih baik lagi, motivasi sudah banyak diterapkan dalam berbagai bidang, motivasi sangat membantu dalam mempengaruhi kearah yang menjadi objek tujuan(Pradnyani, Rahmawati, \& Dkk, 2020).

\subsection{Softskill}

Softskill merupakan kemampuan seseorang secara umum yang dimiliki masing-masing orang berdasarka profesi ataupun bidang yang ia pahami, softskill dapat berupa kemampuan komunikasi, kemampuan memecakan masalah, kecerdasan dalam penguasaan Bahasa dan banyak lainnya. Softskill merupakan kemampuan yang dimiliki dan terbentuk secara alami, ada dengan sendirinya baik berdasarkan kemampuan penyerapan diri terahdap apa yang telah dipelajari tetapi ada juga softskill yang sengaja dibentuk dan dibuat dalam bentuk pelatihan umum, pentingnya ada sebuah softskill yaitu memungkinkan seseorang dalam mengendalikan resiko (Muspah, Gani, \& Ramlawati, 2021).

\subsection{Kinerja Kerja}

Kinerja kerja merupakan hasil yang diperoleh seseorang pekerja dalam mencapai tujuan perusahaan, kinerja merupakan tingkatan, dedikasi, loyalitas dan kepedulian dalam memberikan hal yang terbaik dalam bentuk pekerjaan kepada perusahaan, kinerja kerja merupakan sebuah prioritas yang penting dan selalu dijaga dan ditingkatkan oleh perusahaan demi mencapai keutuhan dan memperoleh laba baik dalam mencapai tujuan bersama, tanpa adanya Kinerja kerja yang optimal dari masig-masing pekerja maka perusahaan akan lebih bergerak lambat dalam mencapai tujuan perusahaan(Prasetyono \& Ramdayana, 2020).

\section{METODE PENELITIAN}

Metode penelitian merupakan hal-hal yang dilakukan dalam sebuah penelitian yang bertujuan memperjelas arah dan tahapan dalam sebuah penelitian, adapun tahapan penelitian dilakukan dalam melihat pengaruh beberapa variabel seperti pengaruh motivasi, pengembangan karir dan softskill, tahapan ini dimulai dengan mengumpulkan data dari beberapa 
narasumber dalam bentuk kuesioner sehingga data tersebut dapat dihitung dan diolah menggunakan aplikasi statistic SPSS Versi 22.

Penelitan ini termasuk kepada penelitian kuantitatif karena data diambil melalui tahapan survei dan dalam bentuk kuesioner yang diubah menjadi data angka sebagai range atau parameter terhadap nilai dan tingkat kepentingan dari masing-masing pertanyaan. Dalam penelitian ini diambil berdasarkan pendapat karyawan secara menyeluruh dimana setiap butir pertanyaan diambil dari beberapa penelitian terkait dalam mendukung tercapainya keputusan dalam sebuah setiap relasi(Akbar et al., 2020).

\subsection{Uji Validitas dan Reliabilitas}

Pada pengujian ini merupakan bagian dari pengujian kolerasi dimana pengujian melihat signifikan pada correlations $<0,05$ terhadap variabel bebas maupun variabel terikat dan adapun kriteria yang harus dicapai yaitu nilai minimum 0,205 sehingga data dianggap valid dan untuk konsisten data biasanya minimum nilai secara menyeluruh harus diatas 0,6 pada Cronbach's Alpha.

\subsection{Uji Asumsi Klasik}

Pada pengujian asumsi klasik untuk melihat apakah terdapat nilai atau distribusi normal atau tidak normal terhadap suatu variabel terikat maupun variabel bebas, pada penelitian ini dilakukan 3 tahapan pengujian yaitu :

1. Uji Normalisasi

Pada pengujian normalisasi digunakan untuk melihat apakah data dinyatakan normal atau tidak dapat dilakukan pengujian parameter terhadap spss dengan signifikasi yang digunakan adalah $>0,05$ sehingga dapat dikatakan normal. Hasil penelitian menunjukan data Asymp. Sig. (2-tailed) sebanyak 0,200 yaitu nilai > 0,05 sehingga data pengujian dinyatakan normal.

2. Uji Multikolinearitas

Pada pengujian ini ingin melihat apakah ada variabel independent atau bebas adanya kolerasi antara keduanya dan perlunya diketahui jika ada maka efek dari hal tersebut yaitu data dinyatakan banyaknya terdapat standart eror. Adapun cara untuk mengetahui adanya multikolinearitas adalah dengan melihat hasil regresi dari spss dari nilai VIFnya atau nila variance inflation factor yaitu"di nilai tolerance rendah sama dengan nilai VIF tinggi, dikarenakan VIF = 1/tolerance, dan menunjukkan terdapat kolinearitas yang tinggi. Nilai cut off yang digunakan adalah untuk nilai tolerance 0,10 atau nilai VIF diatas angka 10 ".

3. Uji Heteroskedastisitas

Uji ini cukup melihat pola dari tumpukan lingkaran yang tersebar secara merata jika tidak berarti data teridentifikasi kebanyakan kembar dan eror terhadap data semakin terdeteksi.

\subsection{Uji Regresi Linear Berganda}

Pada pengujian ini dilakukan pengujian $\mathrm{T}$ dan pengujian $\mathrm{F}$ untuk melihat hubungan antara satu variabel dengan variael lainnya dimana masing-masing data dan parameter yang menyatakan layak, diterima atau tidaknya sebuah data setelah dilakukan pengujian $\mathrm{T}$ dan $\mathrm{F}$ dibantu dengan membandingan parameter dengan tabel $\mathrm{T}$ dan tabel $\mathrm{F}$ dimana tabel tersebut merupakan poros atau patokan dalam melihat hasil dari hipotesis penelitian dihubungkan untuk melihat pengaruh satu variabel dengan variabel lainnya.

\section{HASIL DAN PEMBAHASAN}

Penelitian ini dilakukan untuk melihat pengaruh dan hubungan antara pengaruh variabel Pengembangan Karir, Motivasi, dan Softskill terhadap kinerja karyawan sehingga dilakukan pengujian menggunakan aplikasi perhitungan statistik dengan melihat beberapa hubungan atar satu variabel dengan variabel lainnya, pada tahapan ini sampel sebayak 41 orang karyawan dengan masing-masing variabel memiliki jumlah pertanyaan yang berbeda.

\subsection{Analisis Statistik Deskriptif}

Berikut merupakan data yang diolah dan dilakukan pengujian dengan bantuan dari aplikasi software yang digunakan sebagai alat bantu pengolahan data statistical package for sosial science (SPSS) versi 22.

Tabel 1. Statistik Deskriptif

\begin{tabular}{lrrrrr}
\hline & N & Minimum & Maximum & Mean & $\begin{array}{c}\text { Std. } \\
\text { Deviation }\end{array}$ \\
\hline Motivasi & 41 & 32 & 36 & 33.46 & 1.185 \\
Pengembanga Karir & 41 & 40 & 44 & 41.83 & 1.160 \\
Softskill & 41 & 39 & 44 & 41.51 & 1.247 \\
Kinerja Karyawan & 41 & 31 & 36 & 33.51 & 1.098 \\
Valid N (listwise) & 41 & & & & \\
\hline
\end{tabular}

Hasil diatas memperlihatkan nilai rata-rata, maksimum dan minimum yang dimiliki 
Journal of Business and Economics Research (JBE)

Vol 2, No 3, Oktober 2021, Hal. 66-73

ISSN 2716-4128 (Media Online)

DOI 10.47065/jbe.v2i3.903

\subsection{Uji Validitas}

Pada pengujian ini akan menunjukan data-data dari hasil kuesioner yang telah diisi oleh responden sebagai data yang sah atau tidak adapun hasil yang di dapatkan sebagai berikut ini:

Tabel 2. Uji Validitas Pengembangan Karir

\begin{tabular}{|c|c|c|c|c|c|c|c|c|}
\hline \multicolumn{9}{|c|}{ Correlations } \\
\hline & & $\mathrm{X} 1.1$ & $\mathrm{X} 1.2$ & $\mathrm{X} 1.3$ & $\mathrm{X} 1.4$ & $\mathrm{X} 1.5$ & X1.6 & $\begin{array}{c}\text { Pengembangan } \\
\text { Karir }\end{array}$ \\
\hline \multirow[t]{3}{*}{$\mathrm{X} 1.1$} & Pearson Correlation & 1 & .102 & $.309^{*}$ & .299 & -.063 & -.300 & $.443^{* *}$ \\
\hline & Sig. (2-tailed) & & .525 & .049 & .058 & .695 & .057 & .004 \\
\hline & $\mathrm{N}$ & 41 & 41 & 41 & 41 & 41 & 41 & 41 \\
\hline \multirow[t]{3}{*}{$\mathrm{X} 1.2$} & Pearson Correlation & .102 & 1 & .067 & .159 & .020 & -.194 & $.378^{*}$ \\
\hline & Sig. (2-tailed) & .525 & & .677 & .320 & .901 & .225 & .015 \\
\hline & $\mathrm{N}$ & 41 & 41 & 41 & 41 & 41 & 41 & 41 \\
\hline \multirow[t]{3}{*}{$\mathrm{X} 1.3$} & Pearson Correlation & $.309^{*}$ & .067 & 1 & $.421^{* *}$ & -.041 & -.047 & $.534^{* *}$ \\
\hline & Sig. (2-tailed) & .049 & .677 & & .006 & .797 & .769 & .000 \\
\hline & $\mathrm{N}$ & 41 & 41 & 41 & 41 & 41 & 41 & 41 \\
\hline \multirow[t]{3}{*}{ X1.4 } & Pearson Correlation & .299 & .159 & $.421^{* *}$ & 1 & -.098 & .163 & $.706^{* *}$ \\
\hline & Sig. (2-tailed) & .058 & .320 & .006 & & .541 & .307 & .000 \\
\hline & $\mathrm{N}$ & 41 & 41 & 41 & 41 & 41 & 41 & 41 \\
\hline \multirow[t]{3}{*}{$\mathrm{X} 1.5$} & Pearson Correlation & -.063 & .020 & -.041 & -.098 & 1 & .231 & $.386^{*}$ \\
\hline & Sig. (2-tailed) & .695 & .901 & .797 & .541 & & .146 & .013 \\
\hline & $\mathrm{N}$ & 41 & 41 & 41 & 41 & 41 & 41 & 41 \\
\hline \multirow[t]{3}{*}{ X1.6 } & Pearson Correlation & -.300 & -.194 & -.047 & .163 & .231 & 1 & $.374^{*}$ \\
\hline & Sig. (2-tailed) & .057 & .225 & .769 & .307 & .146 & & .016 \\
\hline & $\mathrm{N}$ & 41 & 41 & 41 & 41 & 41 & 41 & 41 \\
\hline Pengem & Pearson Correlation & $.443^{* *}$ & $.378^{*}$ & $.534^{* *}$ & $.706^{* *}$ & $.386^{*}$ & $.374^{*}$ & 1 \\
\hline bangan & Sig. (2-tailed) & .004 & .015 & .000 & .000 & .013 & .016 & \\
\hline Karir & $\mathrm{N}$ & 41 & 41 & 41 & 41 & 41 & 41 & 41 \\
\hline
\end{tabular}

Berikut ini merupakan merupakan hasil uji validitas variabel motivasi

Tabel 3. Hasil Uji Validitas Variabel Motivasi

\begin{tabular}{|c|c|c|c|c|c|c|c|c|c|c|c|}
\hline \multicolumn{12}{|c|}{ Correlations } \\
\hline & & $\mathrm{X} 2.1$ & $\mathrm{X} 2.2$ & $\mathrm{X} 2.3$ & $\mathrm{X} 2.4$ & $\mathrm{X} 2.5$ & $\mathrm{X} 2.6$ & $\mathrm{X} 2.7$ & $\mathrm{X} 2.8$ & $\mathrm{X} 2.9$ & $\begin{array}{c}\text { Motivasi } \\
\text { Kerja }\end{array}$ \\
\hline \multirow[t]{3}{*}{$\mathrm{X} 2.1$} & Pearson Correlation & 1 & $.611^{* * *}$ & $.545^{* *}$ & $.355^{*}$ & .007 & .216 & .285 & -.072 & -.068 & $.617^{* *}$ \\
\hline & Sig. (2-tailed) & & .000 & .000 & .023 & .964 & .174 & .071 & .656 & .675 & .000 \\
\hline & $\mathrm{N}$ & 41 & 41 & 41 & 41 & 41 & 41 & 41 & 41 & 41 & 41 \\
\hline \multirow[t]{3}{*}{$\mathrm{X} 2.2$} & Pearson Correlation & $.611^{* * *}$ & 1 & $.452^{* * *}$ & .225 & .105 & .234 & -.051 & -.006 & -.102 & $.542^{* *}$ \\
\hline & Sig. (2-tailed) & .000 & & .003 & .157 & .513 & .141 & .751 & .972 & .524 & .000 \\
\hline & $\mathrm{N}$ & 41 & 41 & 41 & 41 & 41 & 41 & 41 & 41 & 41 & 41 \\
\hline \multirow[t]{3}{*}{$\mathrm{X} 2.3$} & Pearson Correlation & $.545^{* *}$ & $.452^{* *}$ & 1 & $.548^{* *}$ & .026 & .230 & .017 & .162 & .138 & $.653^{* *}$ \\
\hline & Sig. (2-tailed) & .000 & .003 & & .000 & .873 & .148 & .918 & .310 & .388 & .000 \\
\hline & $\mathrm{N}$ & 41 & 41 & 41 & 41 & 41 & 41 & 41 & 41 & 41 & 41 \\
\hline \multirow[t]{3}{*}{$\mathrm{X} 2.4$} & Pearson Correlation & $.355^{*}$ & .225 & $.548^{* * *}$ & 1 & .222 & .094 & .129 & .058 & .120 & $.568^{* *}$ \\
\hline & Sig. (2-tailed) & .023 & .157 & .000 & & .164 & .561 & .422 & .721 & .456 & .000 \\
\hline & $\mathrm{N}$ & 41 & 41 & 41 & 41 & 41 & 41 & 41 & 41 & 41 & 41 \\
\hline \multirow[t]{3}{*}{$\mathrm{X} 2.5$} & Pearson Correlation & .007 & .105 & .026 & .222 & 1 & $.448^{* *}$ & $.541^{* *}$ & $.426^{* *}$ & $.410^{* *}$ & $.596^{* *}$ \\
\hline & Sig. (2-tailed) & .964 & .513 & .873 & .164 & & .003 & .000 & .005 & .008 & .000 \\
\hline & $\mathrm{N}$ & 41 & 41 & 41 & 41 & 41 & 41 & 41 & 41 & 41 & 41 \\
\hline \multirow[t]{3}{*}{ X2.6 } & Pearson Correlation & .216 & .234 & .230 & .094 & $.448^{* *}$ & 1 & $.366^{*}$ & .268 & $.363^{*}$ & $.625^{* *}$ \\
\hline & Sig. (2-tailed) & .174 & .141 & .148 & .561 & .003 & & .018 & .090 & .020 & .000 \\
\hline & $\mathrm{N}$ & 41 & 41 & 41 & 41 & 41 & 41 & 41 & 41 & 41 & 41 \\
\hline
\end{tabular}

Berikut ini tabel uji validitas Sotfskill

Tabel 3. Hasil Uji Validitas Variabel Softskill

\begin{tabular}{|c|c|c|c|c|c|c|c|c|c|c|}
\hline \multicolumn{11}{|c|}{ Correlations } \\
\hline & & X3.1 & $\mathrm{X} 3.2$ & X3.3 & X3.4 & X3.5 & X3.6 & X3.7 & X3.8 & Sotfskill \\
\hline \multirow[t]{3}{*}{ X3.1 } & Pearson Correlation & 1 & $.362^{*}$ & .217 & .139 & .046 & .170 & -.118 & .052 & $.531^{* *}$ \\
\hline & Sig. (2-tailed) & & .020 & .173 & .384 & .774 & .289 & .462 & .749 & .000 \\
\hline & $\mathrm{N}$ & 41 & 41 & 41 & 41 & 41 & 41 & 41 & 41 & 41 \\
\hline
\end{tabular}


Journal of Business and Economics Research (JBE)

Vol 2, No 3, Oktober 2021, Hal. 66-73

ISSN 2716-4128 (Media Online)

DOI 10.47065/jbe.v2i3.903

\begin{tabular}{|c|c|c|c|c|c|c|c|c|c|c|}
\hline \multicolumn{11}{|c|}{ Correlations } \\
\hline & & X3.1 & $\mathrm{X} 3.2$ & X3.3 & X3.4 & X3.5 & X3.6 & X3.7 & X3.8 & Sotfskill \\
\hline \multirow[t]{3}{*}{$\mathrm{X} 3.2$} & Pearson Correlation & $.362^{*}$ & 1 & $.344^{*}$ & .008 & $.372^{*}$ & -.028 & $-.317^{*}$ & .035 & $.545^{* *}$ \\
\hline & Sig. (2-tailed) & .020 & & .028 & .959 & .017 & .860 & .043 & .830 & .000 \\
\hline & $\mathrm{N}$ & 41 & 41 & 41 & 41 & 41 & 41 & 41 & 41 & 41 \\
\hline \multirow[t]{3}{*}{ X3.3 } & Pearson Correlation & .217 & $.344^{*}$ & 1 & -.193 & $.445^{* *}$ & -.136 & .096 & -.189 & $.490^{* *}$ \\
\hline & Sig. (2-tailed) & .173 & .028 & & .225 & .004 & .398 & .549 & .236 & .001 \\
\hline & $\mathrm{N}$ & 41 & 41 & 41 & 41 & 41 & 41 & 41 & 41 & 41 \\
\hline \multirow[t]{3}{*}{ X3.4 } & Pearson Correlation & .139 & .008 & -.193 & 1 & .047 & $.550^{* *}$ & .020 & .072 & $.469^{* *}$ \\
\hline & Sig. (2-tailed) & .384 & .959 & .225 & & .771 & .000 & .899 & .653 & .002 \\
\hline & $\mathrm{N}$ & 41 & 41 & 41 & 41 & 41 & 41 & 41 & 41 & 41 \\
\hline \multirow[t]{3}{*}{$\mathrm{X} 3.5$} & Pearson Correlation & .046 & $.372^{*}$ & $.445^{* *}$ & .047 & 1 & -.033 & -.009 & -.181 & $.535^{* * *}$ \\
\hline & Sig. (2-tailed) & .774 & .017 & .004 & .771 & & .836 & .957 & .257 & .000 \\
\hline & $\mathrm{N}$ & 41 & 41 & 41 & 41 & 41 & 41 & 41 & 41 & 41 \\
\hline \multirow[t]{3}{*}{ X3.6 } & Pearson Correlation & .170 & -.028 & -.136 & $.550^{* *}$ & -.033 & 1 & -.137 & .298 & $.458^{* *}$ \\
\hline & Sig. (2-tailed) & .289 & .860 & .398 & .000 & .836 & & .395 & .059 & .003 \\
\hline & $\mathrm{N}$ & 41 & 41 & 41 & 41 & 41 & 41 & 41 & 41 & 41 \\
\hline \multirow[t]{3}{*}{ softskill } & Pearson Correlation & $.531^{* *}$ & $.545^{* *}$ & $.490^{* * *}$ & $.469^{* *}$ & $.535^{* *}$ & $.458^{* *}$ & .151 & .268 & 1 \\
\hline & Sig. (2-tailed) & .000 & .000 & .001 & .002 & .000 & .003 & .346 & .091 & \\
\hline & $\mathrm{N}$ & 41 & 41 & 41 & 41 & 41 & 41 & 41 & 41 & 41 \\
\hline
\end{tabular}

Berikut ini merupakan uji baliditas kinerja karyawan:

Tabel 5. Uji Validitas Variabel Kinerja Karyawan

\begin{tabular}{|c|c|c|c|c|c|c|c|c|c|}
\hline \multicolumn{10}{|c|}{ Correlations } \\
\hline & & Y.1 & Y.2 & Y.3 & Y.4 & Y.5 & Y.6 & Y.7 & Kinerja Karyawan \\
\hline \multirow[t]{3}{*}{ Y.1 } & Pearson Correlation & 1 & .012 & .187 & .061 & .303 & .078 & .063 & $.518^{* * *}$ \\
\hline & Sig. (2-tailed) & & .942 & .241 & .706 & .054 & .626 & 697 & .001 \\
\hline & $\mathrm{N}$ & 41 & 41 & 41 & 41 & 41 & 41 & 41 & 41 \\
\hline \multirow[t]{3}{*}{ Y.2 } & Pearson Correlation & .012 & 1 & -.009 & -.072 & .280 & -.047 & -.014 & .261 \\
\hline & Sig. (2-tailed) & .942 & & .956 & .654 & .077 & .773 & .931 & .099 \\
\hline & $\mathrm{N}$ & 41 & 41 & 41 & 41 & 41 & 41 & 41 & 41 \\
\hline \multirow[t]{3}{*}{ Y.3 } & Pearson Correlation & .187 & -.009 & 1 & .033 & .087 & .024 & -.221 & $.376^{*}$ \\
\hline & Sig. (2-tailed) & .241 & .956 & & .839 & .588 & .883 & .165 & .015 \\
\hline & $\mathrm{N}$ & 41 & 41 & 41 & 41 & 41 & 41 & 41 & 41 \\
\hline \multirow[t]{3}{*}{ Y.4 } & Pearson Correlation & .061 & -.072 & .033 & 1 & .211 & $.365^{*}$ & $.809^{* *}$ & $.674^{* *}$ \\
\hline & Sig. (2-tailed) & .706 & .654 & .839 & & .186 & .019 & .000 & .000 \\
\hline & $\mathrm{N}$ & 41 & 41 & 41 & 41 & 41 & 41 & 41 & 41 \\
\hline \multirow[t]{3}{*}{ Y.5 } & Pearson Correlation & .303 & .280 & .087 & .211 & 1 & .019 & .258 & $.550^{* *}$ \\
\hline & Sig. (2-tailed) & .054 & .077 & .588 & .186 & & .908 & .103 & .000 \\
\hline & $\mathrm{N}$ & 41 & 41 & 41 & 41 & 41 & 41 & 41 & 41 \\
\hline \multirow[t]{3}{*}{ Y.6 } & Pearson Correlation & .078 & -.047 & .024 & $.365^{*}$ & .019 & 1 & $.339^{*}$ & $.534^{* *}$ \\
\hline & Sig. (2-tailed) & .626 & .773 & .883 & .019 & .908 & & .030 & .000 \\
\hline & $\mathrm{N}$ & 41 & 41 & 41 & 41 & 41 & 41 & 41 & 41 \\
\hline \multirow[t]{3}{*}{ Y.7 } & Pearson Correlation & .063 & -.014 & -.221 & $.809^{* *}$ & .258 & $.339^{*}$ & 1 & $.604^{* *}$ \\
\hline & Sig. (2-tailed) & .697 & .931 & .165 & .000 & .103 & .030 & & .000 \\
\hline & $\mathrm{N}$ & 41 & 41 & 41 & 41 & 41 & 41 & 41 & 41 \\
\hline \multirow{3}{*}{$\begin{array}{l}\text { Kinerj } \\
\text { a } \\
\text { Karya } \\
\text { wan }\end{array}$} & Pearson Correlation & $.518^{* *}$ & .261 & $.376^{*}$ & $.674^{* *}$ & $.550^{* *}$ & $.534^{* *}$ & $.604^{* *}$ & 1 \\
\hline & Sig. (2-tailed) & .001 & .099 & .015 & .000 & .000 & .000 & .000 & \\
\hline & $\mathrm{N}$ & 41 & 41 & 41 & 41 & 41 & 41 & 41 & 41 \\
\hline $\begin{array}{l}* * \text {. Co } \\
* \text { * Cor }\end{array}$ & $\begin{array}{l}\text { elation is significant } \\
\text { lation is significant }\end{array}$ & $\begin{array}{l}0.011 \\
.05 \mathrm{le}\end{array}$ & $1(2-t$ & & & & & & \\
\hline
\end{tabular}

Dapat terlihat dari keseluruhan hasil uji validitas variabel bebas maupun variabel terikat tidak memiliki nilai Pearson Correlation negative dan diatas minimum 0,205 sehingga hasil dinyatakan valid atau secara keseluruhan sah untuk dapat dilanjutkan kepada pengujian konsistensi data atau uji Reliabel.

\subsection{Uji Reliabilitas}

Pada pengujian ini dilakukan dengan melihat reliabel pada sebuah data dan nilai data yang digunakan merupakan data keseluruhan variabel terikat dan variabel bebas, hasil yang menyatakan data konsisten jika Cronbach's Alpha dimana nilai dari Cronbach's Alpha harus lebih dari 0,6. Berikut merupakan hasil pengujian reliabilitas pada penelitian ini:

Tabel 6. Uji Reliabilitas 


\begin{tabular}{rr}
\hline $\begin{array}{c}\text { Cronbach's } \\
\text { Alpha }\end{array}$ & N of Items \\
\hline .746 & 25 \\
\hline
\end{tabular}

\subsection{Uji Asumsi Klasik}

Pengujian asumsi klasik biasanya dilakukan pengujian normalisasi, uji multikolinearitas, uji heteroskedastisitas dan lainlain. Tujuan dari uji asumsi klasik ini untuk melihat apakah data terdapat nilai-nilai yang tidak diperlukan dalam sebuah penelitian dan bisa berupa nilai yang mempengaruhi rendahnya sebuah data dan rentannya sebuah data yang ingin diuji. Pada uji asumsi klasik berikut ini memperlihatkan kualitas data pengujian sebelum dilakukan pengujian regresi linear.

\subsubsection{Uji Normalitas}

Signifikasi yang digunakan adalah >0,05 sehingga dapat dikatakan normal. Hasil penelitian menunjukan data Asymp. Sig. (2-tailed) sebanyak 0,200 yaitu nilai > 0,05 sehingga data pengujian dinyatakan normal.

Tabel 7. Uji Normalisasi

\begin{tabular}{llr}
\hline $\mathrm{N}$ & & $\begin{array}{c}\text { Unstandardized } \\
\text { Residual }\end{array}$ \\
\hline Normal Parameters $^{\mathrm{a}, \mathrm{b}}$ & Mean & 50 \\
& & .0000000 \\
Most Extreme Differences & Std. Deviation & 1.45607698 \\
& Absolute & .094 \\
Test Statistic & Positive & .075 \\
& Negative & -.094 \\
Asymp. Sig. (2-tailed) & & .094 \\
& & $.200^{\mathrm{c}, \mathrm{d}}$ \\
\hline
\end{tabular}

Pada penelitian uji normalisasi dapat diketahui dengan melihat gambar grafik yang membentuk gunung yang menunjukan data normal sebagai berikut ini.

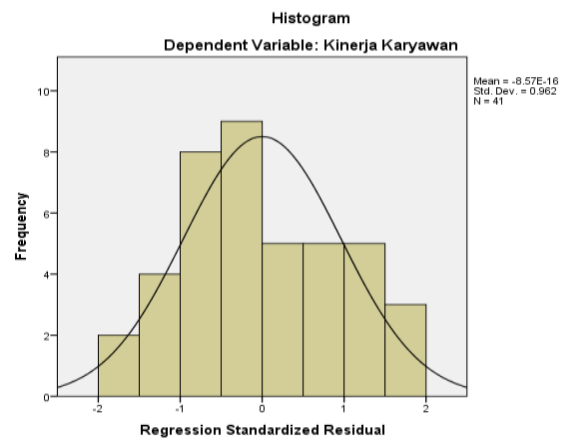

Gambar 1. Histogram Normalisasi.

Data dikatakan normal jika grafik naik dan turun secara alamiah dan tidak terjadi bentuk gunung yang vertical atau horizontal.

\subsubsection{Uji Multikolinearitas}

Pada pengujian ini akan melihat apakah data terkena multikolinearitas yang berarti adanya sebuah data yang intekolerasi atau adanya sebuah data yang koleniaritas pada variabel bebas dan variabel bebas.

Tabel 8. Uji Multikolineritas

\begin{tabular}{|c|c|c|c|c|c|c|c|}
\hline \multirow[b]{2}{*}{ Model } & \multicolumn{2}{|c|}{$\begin{array}{l}\text { Unstandardized } \\
\text { Coefficients }\end{array}$} & $\begin{array}{l}\text { Standardized } \\
\text { Coefficients }\end{array}$ & \multirow[t]{2}{*}{$\mathrm{t}$} & \multirow[t]{2}{*}{ Sig. } & \multicolumn{2}{|c|}{ Collinearity Statistics } \\
\hline & & $\begin{array}{l}\text { Std. } \\
\text { Error }\end{array}$ & & & & Tolerance & VIF \\
\hline 1 (Constant) & 22.883 & 8.282 & & .763 & .631 & & \\
\hline $\begin{array}{l}\text { Pengembangan } \\
\text { Karir }\end{array}$ & .118 & .244 & .080 & 2.485 & .028 & .958 & 12.043 \\
\hline Softskill & -.038 & .092 & -.071 & -.417 & 679 & .903 & 12.107 \\
\hline Motivasi & .165 & .153 & .180 & 2.077 & .088 & .932 & 10.073 \\
\hline a. Dependent Vari & Kinerja Kal & yawan & & & & & \\
\hline
\end{tabular}

Pada pengujian ini dikatakan tidak terkontaminasi jika nilai Tolerance dan Nilai VIF maka dapat ditarik dalam pengambilan keputusan pada uji ini dengan beberapa syarat yaitu: 
a. Jika nilai tolerance lebih besar dari 0,1 berarti tidak ada terjadi gejala multikolinearitas. Adapun nilai pada tolerance variabel $0.958,0.903$ dan 0.932 yang menjukan nilai lebih besar dari 0.1 .

b. Jika nilai VIF lebih kecil dari pada 10, maka artinya tidak terjadi gejala multikolinearitas. Adapun nilai VIF yang dihasilkan dalam pengujian adalah 12.043, 12.107 dan 10.073 yang berarti lebih besar dari 10 .

\subsubsection{Uji Heteroskedastisitas}

Data disebutkan tidak terjadi Heteroskedastisitas adalah jika data yang tampil pada gambar scatterplot titik lingkaran menyebar dan tidak terjadi tumpukan dalam satu area.

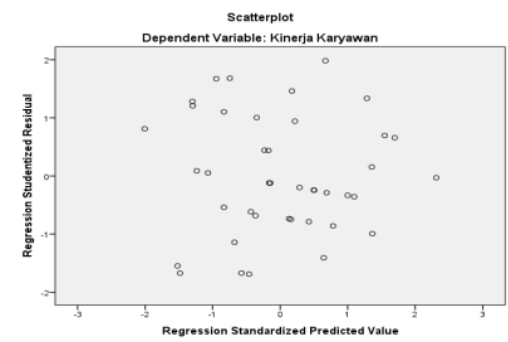

\subsection{Uji Model Regresi}

Gambar 2. Uji Heteroskedastisitas

Pada penelitian pengujian regresi linear berganda digunakan untuk mengetahui pengaruh pengembangan karir, motivasi kerja dan softskill terhadap kinerja karyawan. Sebelum dilakukan pengujian harus ditentukan terlebih dahulu hipotesis peraturan dalam melihat nilai berdasarkan data dan rumus untuk mengetahui hasil dari sebuah pengujian $T$ dan pengujian F dan koefisien terhadap data yang diolah adapun rumusan sebagai berikut ini:

1. Nilai uji t diperoleh dari rumus

$\mathrm{t}$ tabel $=\mathrm{t}(\mathrm{a} / 2 ; \mathrm{n}-\mathrm{k})$ yang berarti $\mathrm{a}=5 \%, \mathrm{n}=$ jumlah responden, $\mathrm{k}=$ variabel

$=\mathrm{t}(0,05 / 2 ; 41-3)$

$=\mathrm{t}(0,025 ; 38)$.

$\mathrm{t}$ tabel harus dilihat pada distribusi tabel nilai $\mathrm{t}$ dengan melihat pada nilai 0,025 pada baris ke 38 maka hasil $\mathrm{t}$ tabel adalah $=2,024$.

2. Nilai uji $F$ diperoleh dari

$\mathrm{F}$ tabel $=\mathrm{f}(\mathrm{k} ; \mathrm{n}-\mathrm{k})=\mathrm{F}(3 ; 41-3)=3 ; 38$ (menggunakan probabilitas 0,05$)$

$\mathrm{F}$ tabel dilihat pada kolom 4 pada baris ke 38 diperoleh angka 2,62.

\subsubsection{Uji T}

Tabel 9. Uji Statistik t (Parsial)

\begin{tabular}{|c|c|c|c|c|c|}
\hline \multirow[b]{3}{*}{ Model } & \multicolumn{3}{|c|}{ Coefficients $^{\mathrm{a}}$} & \multirow{3}{*}{$\mathrm{t}$} & \multirow{3}{*}{ Sig. } \\
\hline & \multicolumn{2}{|c|}{ Coefficients } & $\begin{array}{l}\text { Standardized } \\
\text { Coefficients }\end{array}$ & & \\
\hline & $\mathrm{B}$ & Std. Error & Beta & & \\
\hline $1 \quad$ (Constant $)$ & 22.883 & 8.282 & & .763 & .631 \\
\hline Pengembangan Karir & .118 & .244 & .080 & 2.485 & .028 \\
\hline Sofrskill & -.038 & .092 & -.071 & -.417 & .679 \\
\hline Motivasi & .165 & .153 & .180 & 2.077 & .088 \\
\hline
\end{tabular}

Berdasarkan Tabel 5.10 di atas dapat disimpulkan bahwa nilai statistik $t_{\text {hitung }}$ sebagai berikut :

a. Pengujian Variabel pengembangan karir dengan Kinerja Kerja

variabel pengembangan karir dengan kinerja karyawan terdapat nilai signifikan 0,028 > 0,05, dimana nilai $t_{\text {hitung }}$ harus lebih besar dari $\mathrm{t}_{\text {tabel }} 2,485<2,024$ maka $\mathrm{H}_{0}$ diterima dan $\mathrm{H}_{\mathrm{a}}$ diterima. Dapat dikatakan secara parsial pengembangan karir berpengaruh terhadap kinerja karyawan dan memiliki hubungan yang pengaruh positif.

b. Pengujian Variabel Softskill dengan kinerja karyawan

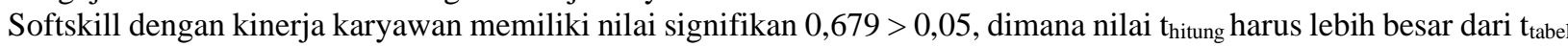
$-0,417<2,024$ maka $\mathrm{H}_{0}$ diterima dan $\mathrm{H}_{\mathrm{a}}$ ditolak. Artinya tidak ada pengaruh yang signifikan secara pasrial antara variabel Softskill dengan kinerja karyawan, dan memiliki hubungan yang negatif.

c. Pengujian Variabel Motivasi dengan kinerja karyawan

nilai ( $t_{\text {hitung }}$ ) pada variabel Motivasi dengan kinerja karyawan dimana memiliki nilai signifikan $0,008<0,05$ dimana nilai $t_{\text {hitung }}$ harus lebih besar dari $t_{\text {tabel }} 2,077>2,024$ maka $\mathrm{H}_{0}$ ditolak dan $\mathrm{H}_{\mathrm{a}}$ diterima. Terlihat adanya pengaruh yang signifikan dan memiliki hubungan positif secara parsial antara variabel Motivasi dengan kinerja karyawan.

\subsubsection{Uji F}

Hasil uji F pada Spss versi 22 memperlihatkan hasl sebagai berikut ini:

Tabel 10. Uji Statistik F (Simultan) 
Journal of Business and Economics Research (JBE)

Vol 2, No 3, Oktober 2021, Hal. 66-73

ISSN 2716-4128 (Media Online)

DOI 10.47065/jbe.v2i3.903

\begin{tabular}{llrrrrr}
\hline \multicolumn{7}{c}{ ANOVA $^{\mathbf{a}}$} \\
Model & & Sum of & & & & \\
\hline 1 & Squares & Df & Mean Square & F & Sig. \\
\hline & Regression & 18.595 & 3 & 6.532 & 3.438 & $.727^{\text {b }}$ \\
& Residual & 129.454 & 37 & 3.499 & & \\
& Total & 134.049 & 40 & & & \\
\hline
\end{tabular}

Berdasarkan tabel 10 terlihat nilai $F_{\text {hitung }}$ pengembangan karir, motivasi kerja, kompetensi terhadap kinerja karyawan sebesar 3,438 sedangkan $\mathrm{F}_{\text {tabel }}$ sebesar $2.85(3,438>2.85)$ dengan DF pembilang $=3$, DF penyebut $=38$ dan taraf signifikan $\mathrm{a}=0.05$ sehingga $\mathrm{F}_{\text {hitung }}>\mathrm{F}_{\text {tabel }}$ sehingga hasil yang didapatkan adalah keseluruhan nilai dan variabel secara bersamaan memiliki nilai signifikasi yang berpengaruh positif.

\section{KESIMPULAN}

Penelitian ini memperlihat antara variabel bebas yaitu pengembangan kariri, Motivasi dan Softskill memiliki nilai yang berbeda terhadap pengaruh masing-masing, pengembangan karir terhadap kinerja kerja memiliki nilai pengaruh positif menurut versi karyawan berdasarkan kuesioner yang diolah, pengaruh positif lainnya yaitu antara variabel moivasi terhadap hasil peningkatan kinerja karyawan dengan hasil hipotesis diterima dan berpengaruh besar, sementara hasil nilai softskill justru memiliki hasil negative terhadap hasil penelitian sehingga peningkatan kinerja karyawan tidak berpengaruh sama sekali.

\section{DAFTAR PUSTAKA}

Akbar, I. R., Prasetiyani, D., \& Nariah, N. (2020). Pengaruh Motivasi Terhadap Kinerja Karyawan Pada Pt. Unggul Abadi Di Jakarta. Jurnal Ekonomi Efektif, 3(1), 84-90. https://doi.org/10.32493/jee.v3i1.7317

Aliyyah, R. R. et all. (2020). Bidikmisi: Analisis Pelaksanaan Program Beasiswa Pendidikan Tinggi. Alignment: Journal of Administration and Educational Management, 3(1), 37-54.

Apriyanti, R., Bahrun, K., \& Finthariasari, M. (2020). PENGARUH KEPEMIMPINAN , REWARD DAN PUNISHMENT TERHADAP KINERJA KARYAWAN ( Studi Kasus Pada PT . K3 / SIL Ketahun Begkulu Utara ). Entrepreneur Dan Manajemen Sains, 1(2), 189-194.

Aren, S., \& Nayman Hamamci, H. (2020). Relationship between risk aversion, risky investment intention, investment choices: Impact of personality traits and emotion. Kybernetes, 49(11), 2651-2682. https://doi.org/10.1108/K-07-2019-0455

Hidayat, R. (2015). Performance Appraisal sebagai Alat Pengukuran Kepuasan Kerja Karayawan. Ilman, 3(1), 1-8.

Hoffmann, C., Spiegl, U. J. A., Hauck, S., Bühren, V., \& Gonschorek, O. (2013). Die ventrale Spondylodese beim älteren Patienten Overtreatment oder sinnvolle Therapieoption? Zeitschrift Fur Orthopadie Und Unfallchirurgie, 151(3), $257-263$. https://doi.org/10.1055/s-0032-1328522

Ismail, I., Hasan, H., \& Musdalifah, M. (2018). Pengembangan Kompetensi Mahasiswa Melalui Efektivitas Program Magang Kependidikan. Edumaspul - Jurnal Pendidikan, 2(1), 124-132. https://doi.org/10.33487/edumaspul.v2i1.48

Muspah, E. Y., Gani, A., \& Ramlawati. (2021). Pengaruh Hard Skill dan Soft Skill Terhadap Kinerja Pegawai pada Kantor Camat Galesong Utara di Kabupaten Takalar. Ilmu Ekonomi, 4(1), 131-142.

Okagbue, H. I., Oguntunde, P. E., Obasi, E. C. M., \& Akhmetshin, E. M. (2021). Trends and usage pattern of SPSS and Minitab Software in Scientific research. Journal of Physics: Conference Series, 1734, 012017. https://doi.org/10.1088/1742$6596 / 1734 / 1 / 012017$

Phadermrod, B., Crowder, R. M., \& Wills, G. B. (2019). Importance-Performance Analysis based SWOT analysis. International Journal of Information Management, 44, 194-203. https://doi.org/10.1016/j.ijinfomgt.2016.03.009

Pradnyani, Rahmawati, \& Dkk. (2020). Pengaruh Reward Dan Punishment Terhadap Motivasi. Jurnal Manajemen Dan Bisnis, 2(1), 21-30.

Prasetyono, H., \& Ramdayana, I. P. (2020). Pengaruh servant leadership, komitmen organisasi dan lingkungan fisik terhadap kin erja guru. Jurnal Akuntabilitas Manajemen Pendidikan, 8(2), 108-123. https://doi.org/10.21831/jamp.v8i2.28458

Robo, S., Trisno, T., Sunardi, S., \& Santosa, S. (2018). Perencanaan strategis sistem informasi menggunakan Enterprise Architecture Planning pada PT. Karya Cipta Buana Sentosa Maumere. Register: Jurnal Ilmiah Teknologi Sistem Informasi, 4(1), 41. https://doi.org/10.26594/register.v4i1.1163 